\title{
A Study on the Association between Operating Leverage and Risk: The Case of the Airline Industry
}

\author{
Soin Lee ${ }^{1} \&$ Sang-Bum Park ${ }^{1}$ \\ ${ }^{1}$ Department of Business Administration, The Graduate School, Korea Aerospace University, Korea \\ Correspondence: Sang-Bum Park, Professor, Department of Business Administration, The Graduate School, \\ Korea Aerospace University. 76 Hanggondaehang-ro, Deogyang-gu, Goyang-city, Gyeonggi-do, 412-791, Korea. \\ E-mail: psb@kau.ac.kr
}

Received: October 08, 2013

Accepted: December 18, $2013 \quad$ Online Published: February 25, 2014

doi:10.5539/ijef.v6n3p120

URL: http://dx.doi.org/10.5539/ijef.v6n3p120

\begin{abstract}
In this study we investigated the hypothesis that both the overall risk (volatility) of a firm and the systematic risk of common stock of a firm in an industry are positively associated with the degree of operating leverage, or negatively associated with firm's level of variable costs. We focused on the airline industry. The profits of the airline industry depend on business cycle. The operating leverage amplifies the rate of change of profits and thus Earings per Share. The airline industry holds high operating leverage due to its industry structure. The test results show that the empirical results are consistent with the hypotheses that the average variable cost component is negatively associated with both the overall and systematic risk measures for the airline industry. Therefore for a manager in the industry it is very important to manage the level of operating leverage.
\end{abstract}

Keywords: operating leverage, overall risk, systematic risk, book-to-market equity ratio, returns, airline industry

\section{Introduction}

The main purpose of a firm is shareholders' profit maximization. For shareholders' profit maximization, a firm must earn profit. That is, profitability is the most important for firms. Profitability for a firm depends on many factors inside and outside. The most influential outside factor is market condition.

The rate of change of profits by market condition is different according to industry. One inside factor that affects the rate of change of profits is operating leverage. Some industries hold high operating leverage due to the structure of the industry itself. For example, electric utilities, steel manufacturers and oil producers hold high operating leverage.

According to Porter (1996), "industry structure has a strong influence in determining competitive rules of the game as well as the strategies which are potentially available to the company".

Operating leverage is defined as the ratio of the fixed costs relative to variable costs. Average operating leverage is different depending on industries. Some industries such as electric utilities, steel manufacturers, and oil producers are known as high operating leverage. The airline industry is also notorious for its high operating leverage. Operating leverage acts like leverage itself to the level of change as sales. The higher the operating leverage is, the higher the change of profits is.

The profits of the airline industry are very sensitive to the business cycle. When the business is boom, more seats are demanded and vice versa. The more seats indicate more airplanes. Then airliners should be prepared to it. However an airplane is not ready-made good. There is time gap between airplane order and delivery approximately 2-3 years according to the capacity of the manufacturer and amounts of orders. So a manager of an airline company should be able to forecast the business cycle and determine the size of seat to provide. Failure to meet increasing demand means losing market shares, blemish to the brand name, and diminishing customer loyalty.

The operating leverage will be one important factor influencing the determination regarding new orders of planes. Ordering new airplanes will increase inevitably operating leverage and higher operating leverage increases in turn the fluctuations of Earnings per Share which managers and investors are concerned most and react very sensitively. 
Given the substitutability among production factors, for the airline industry ordering new planes for example, the degree of operating leverage can be substantially changed by managerial decisions too in the airline industry like electric utilities, steel manufacturers and oil producers. Operating leverage has attracted interests of many researchers in lieu of so-called value premium. That is, recent theoretical models predict an association between the book-to-market equity ratio and operating leverage and average stock returns (e.g., Carson, Fisher, \& Giammarino, 2004; Cooper, 2006).

This research is to investigate the effect of the firm's operating leverage on the riskiness and hence market value of its shares. We revisit operation leverage because some industries like the airline industry the operation leverage is a very important factor affecting sustainability of a firm. The main objective of this research is to investigate the relationship between operating leverage and risk is to advance the understanding of the risk-generating process operating in capital markets for the airline industry.

The modern capital structure theory has been constructed based on the Modigliani and Miller (1958) assumptions. Many studies have attempted to explain how companies choose their capital structure in a theory. For example, Adrian and Shin (2010), Christie (1982), Kraus et al. (1973), Lang et al. (1996), investigated liquidity and leverage, leverage and value, leverage related model, leverage and growth, etc. Such efforts have been inconclusive, that is, no capital structure can be categorically indicated to be better than any other.

Studies have revealed that operating leverage is one of the determinants of systematic risk (Note 1). Mandelker and Rhee (1984) decompose a firm's systematic risk into degree of operating leverage, degree of financial leverage, and business risk.

Recent studies (e.g., Carlson, Fisher, \& Giammarino, 2004) try to investigate an association between book-to-market ratio and operating leverage. This argument is based on considerable evidence that stocks with high values of the book-to-market equity ratio have historically earned higher returns than stocks with low values of the ratio. Regarding this argument, there are two ideas whether the nature of the systematic risk underlying the value premium comes from financial distress or investment activity. For example, Fama and French (1992), Cheng and Zhang (1998), and Griffin and Lemmon (2002) suggest that the book-to-market effect is due to priced financial distress risk. On the other hand, Berk, Green and Naik (1999), Gomes, Kogan, and Zhang (2003), Carson, Fisher, and Giammarino (2004), Zhang (2005) and Cooper (2006) suggest that the value premium is related to firm-level investment activity.

In this context, for the airline industry, purchasing planes can be regarded as investment activity as well as a main factor affecting operating leverage. So instead of finding whether purchasing planes is investment activity or financial distress, we analyze the relationship between operating leverage and risk and correlations between operating leverage and returns and correlations between operating leverage and book-to-market equity ratio.

\section{Operating Leverage and Risk}

Here calculating operating leverage, we follow Lev (1974). According to the basic accounting principle, a firm's before-tax net earnings during period $\mathrm{t}, X_{i, t}$, may be defined as:

$$
X_{i, t}=R_{i, t}-V_{i, t}-F_{i, t}
$$

where, $R_{i, t}=$ total revenues during $\mathrm{t}$;

$V_{i, t}=$ total variable costs, which are a function of number of units sold during $\mathrm{t}$;

$F_{i, t}=$ total fixed costs (including interest and preferred dividend) unaffected by volume changes during $\mathrm{t}$.

The after-tax earnings, where $\tau$ is the average (and marginal) corporate tax rate, are:

$$
X_{i, t}(1-\tau)=\left(R_{i, t}-V_{i, t}-F_{i, t}\right)(1-\tau)
$$

The relationship between the firm's earnings and the return on its common stock during period $t, r_{i, t}$, is:

$$
r_{i, t}=d_{i, t}+C g_{i, t}=\frac{X_{i, t}(1-\tau)+\Delta g_{i, t}}{S_{i, t-1}}
$$

where,

$d_{i, t}=$ dividends per share during $\mathrm{t}$;

$C g_{i, t}=$ change in capitalized growth during $\mathrm{t}$;

$S_{i, t-1}=$ total market value of common stock at the beginning of $\mathrm{t}$.

The rate of return on a stock during $t$ is equal to the after-tax earnings accruing, $x_{i t}(1-\tau)$, plus change in the capitalized growth, $\Delta \mathrm{g}_{\mathrm{it}}$, divided by the total market values of the stocks, $\mathrm{s}_{\mathrm{i}, \mathrm{t}-1}$. 
In reality, demand $\mathrm{Q}_{\mathrm{it}}$, sales, variable costs are random variables, and thus earnings are random variables.

$$
X_{i t}=(P Q)_{i t}-(V Q)_{i t}-F_{i t}
$$

where, $\mathrm{p}=$ average price per unit of the product,

$\mathrm{V}=$ average variable costs per unit of the product.

Differenciating the equation (4) with respect to $\mathrm{Q}_{i t}$ yields equation (5).

$$
X_{i t}^{\prime}=P_{i t^{-}} V_{i t}
$$

In equation (5) the fixed costs, $\mathrm{F}_{\mathrm{it}}$, vanishes. This means that within specified range demand fluctuation does not affect fixed costs. The derivative of earnings with respect to demand, $X_{i t}$, equals the difference between the product's average price and the average variable costs (Note 2).

The differences in operating leverage among firms in the same industry will be reflected in different average variable costs, $\mathrm{V}_{\mathrm{it}}$, and thus in different earnings derivatives, $\mathrm{X}_{\mathrm{it}}{ }^{\prime}$.

To see the relationship between variables, $V_{i t}$ and $X_{i, t}$ let's consider two firms, firm 1 and firm 2 . Firm 1 has a higher operating leverage than firm 2. Then $V_{1, t}<V_{2, t}$, and $X_{1, t}>X_{2, t}$. That is firm 1's earnings volatility induced by demand fluctuations will be higher than that of firm 2 . The higher the operating leverage the higher.

From equations (1), (3), we can tell that if other things are equal, the higher the operating leverage is the larger the volatility of returns are. So, if $\mathrm{V}_{1, \mathrm{t}}<\mathrm{V}_{2, \mathrm{t}}$, the derivative of the firm 1' stock returns with respect to demand, $\partial r_{1 t} / \partial Q_{1 t}$ will be larger than that of the firm 2's return, $\partial r_{2 t} / \partial \mathrm{Q}_{2 t}$. The volatility of returns is regarded as the overall risk of a stock. The volatility of a stock is measured by the standard deviation of quarterly returns below.

According to CAPM, the systematic risk is represented by 8 , which is defined as follows.

$$
\beta_{i}=\frac{\operatorname{cov}\left(r_{i t}, r_{M T}\right)}{\sigma^{2}\left(r_{M T}\right)}
$$

where $\mathrm{r}_{\mathrm{MT}}=$ return on the market portfolio during period $\mathrm{t}$.

If equation (2) and (3) are substituted in equation (6), we can have the following equations (7) and (7a).

$$
\begin{gathered}
\beta_{i}=\frac{\operatorname{cov}\left[\frac{\left(R_{i t}-V_{i t}-F_{i t}\right)(1-\tau)+\Delta g_{i t}}{s_{i, t-1}}, r_{M T}\right]}{\sigma^{2}\left(r_{M T}\right)} \\
s_{i, t-1} \beta_{i}=\frac{\operatorname{cov}\left[\left(R_{i t}-V_{i t}-F_{i t}\right)(1-\tau)+\Delta g_{i t} r_{M T}\right]}{\sigma^{2}\left(r_{M T}\right)}=\frac{\operatorname{cov}\left[R_{i t}(1-\tau), r_{M T}\right]}{\sigma^{2}\left(r_{M T}\right)}-\frac{\operatorname{cov}\left[V_{i t}(1-\tau), r_{M T}\right]}{\sigma^{2}\left(r_{M T}\right)}+\frac{\operatorname{cov}\left[\Delta g_{i t}, r_{M T}\right]}{\sigma^{2}\left(r_{M T}\right)}
\end{gathered}
$$

Here let's assume two firms 1 and 2 in the same industry with a different degree of operating leverage. In the industry, the pattern of sales across the state of nature is identical. That is,

$$
R_{1 t}(\theta)=R_{2 t}(\theta)
$$

where $\mathrm{R}_{\mathrm{i}, \mathrm{t}}(\theta)=$ sales of firm i during period $\mathrm{t}$ if state $\theta$ occurs.

In equation (7a), on the right hand side, the first covariance between sales and market return will be the same for the two firms. And the third covariance between the rate of growth and market return can be regarded as the same because in a given condition and in the same industry growth of a firm will be depended mainly on the output pattern that is not affected by differences in the mix of fixed and variable costs. But the second covariance between variable costs and the market return will be different for the two firms. The firm 1 has the higher operating leverage and thus will have a lower level of variable costs than firm 2. Accordingly the firm 1 will have a lower covariance with the market return.

Therefore, since

$$
\frac{\operatorname{cov}\left[V_{l t}(1-\tau), r_{M T}\right]}{\sigma^{2}\left(r_{M T}\right)}<\frac{\operatorname{cov}\left[V_{2 t}(1-\tau), r_{M T}\right]}{\sigma^{2}\left(r_{M T}\right)}
$$

We can tell that from $(7 a)$,

$$
S_{1, t-1} \beta_{1}>S_{2, t-1} \beta_{2}
$$

The inequality (10) expresses that the product of the higher operating leverage firm's total stock value and its systematic risk is larger than the lower operating leverage firm's total stock value and its systematic risk. If we assume $S_{1, t-1}=S_{2, t-2}$, that is the total stock values of the firms are equal, the systematic risk of the firm with higher operating leverage will be larger than that of the firm with lower operating leverage. That is, $\beta_{1}>\beta_{2}$.

Considering the identity of the sales pattern across the states of nature (8), especially in the airline industry, the 
assumption concerning the equality of the total stock values of the two firms seems tenable. In equilibrium condition, in spite of different efficiencies or input mixed, the market value of stocks plus the present value of future factor payments will be shown to be the same for all firms with the same output stream, $R_{\mathrm{it}}(\theta)$ (Note 3 ). Therefore if there is no systematic effect to the present value of total factor payments by different levels of operating leverage, the stocks' market value with identical output stream will be the same, and the inequality (10) holds.

\section{Test Design}

In this study we are trying to investigate that the relationship between both the overall risk (volatility) and the systematic risk of common stocks and the level of variable costs. We presume that both the overall risk and the systematic risk of common stocks will be positively related to the degree of operating leverage for the airline industry.

To test the relationship, we have to determine the average variable costs of each firm shown in (5) and (9) and (10).

One way of finding variable costs out of total operating costs is running a regression as follows.

$$
T C_{i t}=a_{i}+V_{i} Q_{i t}+u_{i t}
$$

where $T C_{i t}=$ total operating costs of firm i during year $\mathrm{t}$ and,

$Q_{i t}=$ physical output of firm i during year t. physical output (sales) for the firm.

In this case the estimated coefficient $v_{i}$ is a surrogate for the firm's average variable costs per unit of output. However, for the airline industry costs items are provided. So we do not need to follow the above rigorous process.

Risk measures for each firm were obtained by the following methods. Overall volatility was measured as the standard deviation of quarterly returns over the 2002-2007. And systematic risk estimates, $\beta_{\mathrm{i}}$ 's, were obtained from the following model (Note 4).

$$
r_{i t}=\alpha_{i}+\beta_{i} r_{\mathrm{MT}}+u_{i t}, t=1,2,3, \ldots, 24(2002-2007)
$$

Where $r_{i t}=$ quarterly return on stock $\mathrm{i}$,

$r_{\mathrm{MT}}=$ New York Stock Exchange arithmetic average index of quarterly returns.

The residual, $\mathrm{u}_{\mathrm{it}}$, conditions are those assumed by OLS model.

Here we use quarterly data because RITA (Research and Innovative Technology Administration Bereau of Transportation Statistics) data is provided as quarterly basis.

Then two risk measures were cross-sectionally regressed for the airline industry on the unit variable cost estimate, $\mathrm{v}_{\mathrm{i}}$, calculated from above.

\section{Data and Analysis}

$$
\begin{gathered}
\sigma\left(r_{i}\right)=a_{1}+b_{1} \hat{v}_{i}+\epsilon_{1 i} \\
\beta_{i}=a_{2}+b_{2} \hat{v}_{i}+\epsilon_{2 i}
\end{gathered}
$$

Data set came from RITA and Valueline. We selected 10 airliners during 2002-2007. RITA provides expense items as follows. Flying Operations, Maintenance, Passenger Service, Aircraft And Traffic Service, Promotion And Sales, General And Administrative (68000), General And Administrative (69000), Depreciation and Amortization, Transport Related Expenses, are those. Among them, Flying Operations, Passenger Service, Aircraft and Traffic Service, Transport Related Expenses are classified as operating expenses.

Estimated coefficients for equations (13) and (14) are reported in tables 1 and 2. And regression estimates for the electric utilities are provided for comparison. 
Table 1. Regression estimates for equation 13

\begin{tabular}{ccccc}
\hline Industry & No. of firms & $\mathrm{R} 2$ & $\mathrm{a} 1$ & $\mathrm{~b} 1$ \\
\hline \multirow{2}{*}{ Airline Industry } & 10 & 0.26 & 0.1192 & -0.1121 \\
& & & $(3.906)$ & $(-3.011)$ \\
Electric Utilities & 75 & 0.12 & 0.056 & -0.4953 \\
& & & $(21.650)$ & $(-1.989)$ \\
\hline
\end{tabular}

Note: Values in the parentheses are t-values. Estimates of Electric Utilities are from the research results by Lev(1974).

Table 2. Regression estimates for equation 14

\begin{tabular}{ccccc}
\hline Industry & No. of firms & $\mathrm{R} 2$ & $\mathrm{a} 1$ & $\mathrm{~b} 1$ \\
\hline \multirow{2}{*}{ Airline Industry } & 10 & 0.21 & 1.5524 & -1.9017 \\
& & & $(3.7291)$ & $(-2.311)$ \\
Electric Utilities & 75 & 0.08 & 0.5149 & -6.912 \\
& & & $(14.790)$ & $(-2.060)$ \\
\hline
\end{tabular}

Note: Values in the parentheses are t-values.

From the reports in tables (1) and (2), it is shown that the empirical results are consistent with the hypotheses that the average variable cost component is negatively associated with both the overall and systematic risk measures for the airline industry.

Next we conducted correlation test with regard to operating leverage (DOL) and returns and operating leverage (DOL) and book-to-market equity ratio (BE/ME). The followings are the results.

Table 3. Pearson correlation coefficients for the test variables

\begin{tabular}{cccc}
\hline & Returns & Ln BE/ME & LLn DOL \\
\hline Ln BE/ME & 0.087 & & \\
Ln DOL & 0.032 & 0.211 & \\
\hline
\end{tabular}

From Table 3, we can see that there is positive relationship between operating leverage and returns and also there is positive relationship between book-to-market equity ratio and operating leverage and book-to-market equity ratio.

\section{Conclusion}

In this study we investigated the hypothesis that both the overall risk (volatility) of a firm and the systematic risk of common stock of a firm in an industry are positively associated with the degree of operating leverage, or negatively associated with firm's level of variable costs. In addition to that we tested the relationship between operating leverage and returns and operating leverage and book-to-market equity ratio. We focused on the airline industry. The profits of the airline industry depend on business cycle. The operating leverage amplifies the rate of change of profits and thus Earnings per Share. The airline industry holds high operating leverage due to its industry structure.

The test results show that the empirical results are consistent with the hypotheses that the average variable cost component is negatively associated with both the overall and systematic risk measures for the airline industry. And there is quite strong positive relationship between operating leverage and returns and operating leverage and book-to-market equity ratio. Therefore for a manager in the industry it is very important to manage the level of operating leverage.

As Chin and Tay (2001) indicate the key implications for airliners are to improve their forecasting techniques, capacity flexibility and responsiveness to the changing environment. 


\section{References}

Adrian, T., \& Hyun, S. S. (2010, July). Liquidity and leverage. Journal of Financial Intermediation, 19(3), 418437. http://dx.doi.org/10.1016/j.jfi.2008.12.002

Chin, A., \& John, H. T. (2001). Developments in air transport: Implications on investment decisions, profitability and survival of Asian airliners. Journal of Air Transport Management, 7, 319-330. http://dx.doi.org/10.1016/S0969-6997(01)00026-6

Christie, A. A. (1982, December). The stochastic behavior of common stock variance: Values, leverage and interest rate effects. Journal of Financial Economics, 10(4), 407-432. http://dx.doi.org/10.1016/0304-405X(82)90018-6

Kraus, A., \& Robert, H. (1973, September). Litzenberger, a state-preference model of optimal financial leverage. Journal of Finance, 28(4), 911-922. http://dx.doi.org/10.1111/j.1540-6261.1973.tb01415.x

Lang, L., Eli, O., \& Rene, M. S. (1996, January). Leverage, investment, and firm growth. Journal of Financial Economics, 40(1), 3-29. http://dx.doi.org/10.1016/0304-405X(95)00842-3

Lev, B. (1974, September). On the association between operating leverage and risk. Journal of Financial and Quantitative Analysis, 627-641. http://dx.doi.org/10.2307/2329764

Mandelker, G. N., \& Ghon, R. S. (1984). The impact of the degrees of operating and financial leverage on systematic risk of common stock. Journal of Financial and Quantitative Analysis, 29, 45-57.

Porter, M. E. (1996). What's in strategy? Harvard Business Review, 61-78. http://dx.doi.org/10.2307/2331000

\section{Notes}

Note 1. Lev (1974), Mandelker and Rhee (1984) report that evidence of a positive association between operating leverage and systematic risk.

Note 2. This is known as contribution margin.

Note 3. Refer to Diamond, P. A. (1967). The Role of a Stock Market in a General Equilibrium Model with Technological Uncertainty. American Economic Review, 57, 759-776.

Note 4. This is called diagonal model or market model.

\section{Appendix}

Airliners listed

ALK: ALASKA AIR GROUP INC;

CPA: COPA HOLDINGS SA;

ALGT: ALLEGENT TRAVEL CO;

RYAAY: RYANAIR HOLDINGS PLC;

DAL: DELTA AIR LINES INC;

LUV: SOUTHWEST AIRLINES;

LCC: US AIRWAYS GROUP INC;

SAVE: SPIRIT AIRLINES INC;

HA: HAWAIIAN HOLDINGS INC;

SKYW: SKYWEST INC.

\section{Copyrights}

Copyright for this article is retained by the author(s), with first publication rights granted to the journal.

This is an open-access article distributed under the terms and conditions of the Creative Commons Attribution license (http://creativecommons.org/licenses/by/3.0/). 